\section{KEY POINTS}

- The Government of the People's Republic of China developed proactive climate policies to decarbonize its economy as pledged at the Paris Agreement. To scale up climate investments, public sector resources are insufficient; private sector participation is required to bridge the funding gap and bring in advanced technologies.

- There is a vast need for climate-related investments going beyond business-as usual. A new paradigm shift going beyond traditional financing and banking modalities is needed to unlock significant climate finance and crowd in private institutional and commercial funding in a sustainable manner.

- Key areas for policy action include (i) creating an enabling environment to cater to climate financing requirements for longer term; and (ii) building up climate finance capacity and knowledge. These policies will help overcome barriers in climate finance, such as affordability constraints, and first-mover and behavioral risks.

\title{
Catalyzing Climate Finance with the Shandong Green Development Fund
}

\author{
Hubert Jenny \\ Former Principal Infrastructure \\ Finance Specialist \\ East Asia Department (EARD) \\ Asian Development Bank (ADB) \\ Yihong Wang \\ Senior Investment Officer \\ EARD \\ Asian Development Bank \\ Bharat Dahiya \\ Consultant \\ Asian Development Bank
}

\author{
Frédéric Asseline \\ Principal Climate Change Specialist \\ (Climate Finance) \\ Sustainable Development and Climate \\ Change Department \\ Asian Development Bank \\ Anouj Mehta \\ Principal Infrastructure Specialist \\ Southeast Asia Department \\ Asian Development Bank \\ Michael Lindfield \\ Consultant \\ Asian Development Bank
}

ISBN 978-92-9262-270-1 (print) ISBN 978-92-9262-271-8 (electronic) ISSN 2071-7202 (print) ISSN 2218-2675 (electronic) Publication Stock No. BRF200192-2 DOI: http://dx.doi.org/10.22617/BRF200192-2
In 2019, the Asian Development Bank (ADB) approved a $\$ 100$ million loan contributing to climate finance for the $\$ 1.5$ billion Shandong Green Development Fund Project. The fund introduces an innovative leveraging mechanism to catalyze private, institutional, and commercial capital for the development of climate-friendly infrastructure and business in Shandong Province, the People's Republic of China (PRC). The project focuses on the twin strategic agendas of environmentally sustainable growth and inclusive economic growth. The fund will finance a portfolio of mitigation and adaptation projects assessed against both financial and climate eligibility criteria using the Green Climate Fund investment framework. The project will contribute to the transition to low-carbon and climate-resilient development paths in Shandong Province. The fund will act as the financial arm of the Shandong Provincial Government to implement its progressive climate policies and to decarbonize its economy. The fund holds seed capital of $\$ 400$ million from international financial institutions, $\$ 360$ million from public sources, and $\$ 740$ million from private investors to cofinance about $\$ 7.5$ billion of climate-positive investment, achieving a leveraging ratio of over 1:5. By 2027, the fund aims to contribute to (i) climate change mitigation, measured through carbon emission reductions of 3.75 million tons annually, and (ii) climate change adaptation, measured through improvement in climate resilience of over 3 million beneficiaries. It is the first climate fund in the PRC to be categorized as effective gender mainstreaming. 


\section{NATIONAL CLIMATE POLICY CONTEXT IN THE PEOPLE'S REPUBLIC OF CHINA}

In recent decades, global development policies focused almost exclusively on the growth of gross domestic product (GDP), to the detriment of holistic sustainable development. This has been paralleled by the worsening impacts of climate change. In order to tackle these increasingly important challenges, especially in the Asia and Pacific region, the PRC plays a pivotal role. Going beyond the well-trodden path of GDP-oriented development, the Government of the PRC in 2010 committed itself to promote ecological civilization. ${ }^{1}$ In the same vein, the PRC announced climate targets in the form of Intended Nationally Determined Contributions (INDC) as its commitment to climate change actions by $2030,{ }^{2}$ especially to "achieve the peaking of emissions around 2030 and making best efforts to peak early" included into 2015 Paris Agreement on climate change. ${ }^{3}$

The Government of the PRC initiated a range of measures on green finance. In 2013, as part of the PRC's 12th Five Year Plan, plans for a green bond market were announced. The PRC also promulgated the country's Green Bond Guidelines and Eligible Project Catalogue. As a result, the PRC emerged as the largest sovereign issuer of green bonds; the country represents one-third of the world's green bond issuance. Other relevant initiatives by the PRC include (i) the State Council's approval in 2016 of the Guideline for Establishing the Green Financial System to incentivize and promote green loans, green bonds, green funds, green insurance, and mandatory environmental information disclosure, among others; and (ii) the launch of the national carbon trading scheme, which could become the world's largest domestic carbon market; this will initially encompass more than one-third of the country's annual total carbon dioxide $\left(\mathrm{CO}_{2}\right)$ emissions.

This paper shows how the Shandong Green Development Fund (SGDF) addresses the identified policy constraints to climate change finance, and supports (i) ADB Strategy 2030 key operational area on climate change; ${ }^{4}$ (ii) the Sustainable Development Goals (SDGs), SDG 9: Industry, Innovation, and Infrastructure, by building climate-resilient infrastructure; (iii) promotion of green businesses and fostering of a new climate finance model; and (iv) SDG 13: Climate Action, by taking urgent actions to promote climate-related investments to combat climate change impact. The project is designed as a systemic response to constraints in financing climate-friendly investments and as such addresses the following key policy areas: (i) supply side, by improving access to capital market and much needed private, institutional, and commercial (PIC) finance to supplement limited public funding; (ii) demand side, by promoting transformational climate investments maximizing climate benefits to better contribute to the SDGs in general, and the INDC in particular; and, (iii) operational constraints with limited capacity at the level of the local governments to define, prepare, finance, and implement climate investment programs supporting the progressive climate policy framework in place in the PRC and in Shandong Province.

\section{PILOTING THE SHANDONG GREEN DEVELOPMENT FUND}

Shandong is an eastern province of the PRC and part of the economically dynamic Beijing-Tianjin-Hebei area. Located on the Yellow Sea, it has a coastline of around 3,000 kilometers. In 2017, its population was just under 100 million and contributed about $8.9 \%$ of the national GDP. In terms of GDP per capita, Shandong is ranked eighth among all provinces in the PRC. Jinan, the provincial capital, ranks 21st in terms of GDP per capita out of all 34 provincial capitals; it was also ranked the most congested city in the PRC.

The State Council of the PRC designated Shandong Province to pilot a shift away from a GDP growth orientation toward a lowcarbon and climate-resilience growth paradigm. If such a shift is successful in this pilot province, it will provide hands-on experience for its replication across the nation. However, the twin challenges of economic transformation and achieving climate-related targets will require better access to climate finance.

Shandong Province was selected as a pilot for the ADB-financed project due to two key factors. ${ }^{5}$ First, Shandong is a highly industrialized province, which is reflected in the fact that it has the highest consumption of coal per capita and energy in the PRC. The workforce and extensive old industrial investment in the province faced multiple climate vulnerabilities. Tight resource constraints and environmental constraints as well as accelerated urbanization processes pose unprecedented threats to the economic development and climate agendas in the province. Second, Shandong Province has a track record of making concerted efforts on climate change issues: (i) establishing the New Industry Development Guidance Fund in 2019; (ii) incorporating carbon intensity reduction goal into the economic and social development plans in line with the countrywide requirement; ${ }^{6}$ and (iii) making focused efforts to shift from highpace economic growth to high-quality development, especially due to the pressure to reduce carbon intensity. Shandong is now in a critical period of transforming its development patterns and growth momentum to optimize its economic structure by decarbonizing its economy.

\footnotetext{
The purpose behind the notion of ecological civilization is to work toward achieving harmony between human beings and nature and, in turn, developing a low-carbon economy.

2 United Nations. 2016. Paris Agreement. Paris.

3 Government of the People's Republic of China. 2015. Intended Nationally Determined Contributions. Beijing.

4 ADB. 2018. Strategy 2030: Achieving a Prosperous, Inclusive, Resilient, and Sustainable Asia and the Pacific. Manila.

5 ADB. 2019. Report and Recommendation of the President to the Board of Directors: Proposed Loan to the People's Republic of China for Shandong Green Development Fund Project. Manila.

6 By 2020, Shandong is required to reduce its $\mathrm{CO}_{2}$ emission intensity by $20.5 \%$ from the 2015 level. This is the toughest provincial-level target set in the PRC.
} 
Figure 1: Portfolio Distribution (Shandong Green Development Fund)

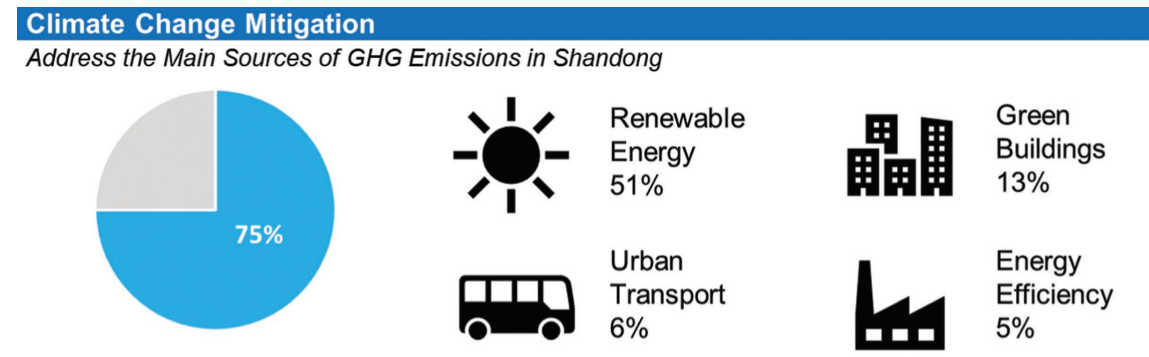

Climate Change Adaptation Improve People's Climate Resilience
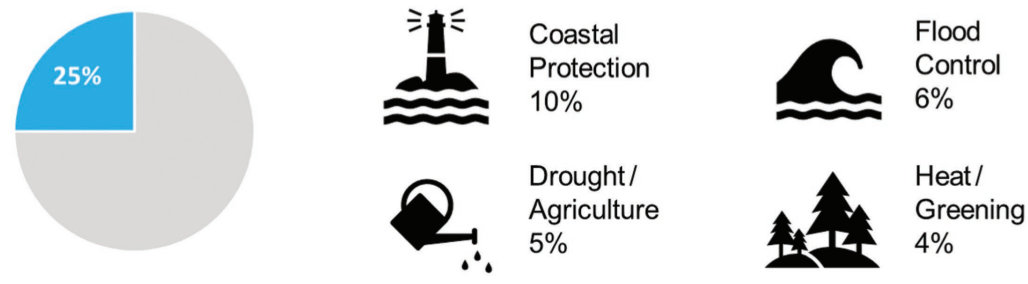

GHG = greenhouse gas.

Source: ADB. 2019. Report and Recommendation of the President to the Board of Directors: Proposed Loan to the People's Republic of China for Shandong Green Development Fund Project. Manila.

\section{CLIMATE FINANCE PRIORITIES IN SHANDONG PROVINCE}

Shandong Province has prioritized a number of sectors following a climate vulnerability assessment completed at provincial scale funded by ADB. The assessment includes a greenhouse gas (GHG) emissions profile per sector for mitigation and climate resilience impact for adaptation. The climate vulnerability assessment analyzes the sectors where climate financing can make the greatest contribution to the achievement of Shandong's provincial policy objectives both in terms of climate change mitigation and adaptation.

The assessment concluded that the main sources of GHG emissions in Shandong Province are energy production, buildings, and rapidly growing urban transport. Consequently, the climate change mitigation priorities of the SGDF are (i) renewable energy production, including wind, solar, biomass, and geothermal; (ii) green buildings; and (iii) low-carbon transport. Further, the climate change adaptation priorities are (i) irrigation and integrated urban water management, including flood control and proofing, through low-impact development for urban areas (sponge cities, urban heat islands, and greening); and (ii) coastal protection. The SGDF targets an allocation of $75 \%$ financing for mitigation and $25 \%$ for adaptation to emphasize the priority of the province to meet its tough carbon emission reduction targets (Figure 1).

\section{ADB AND GREEN FINANCE IN THE PEOPLE'S REPUBLIC OF CHINA}

ADB's commitment to support the PRC's reform agenda of "managing climate change and the environment" is reflected in its country partnership strategy, 2016-2020.7 The SGDF supports ADB's Strategy 2030 (footnote 4) with regard to tackling climate change by fully integrating climate change mitigation and adaptation into project design, contributing to increase climate finance targets, and accelerating low GHG development in line with the PRC's commitments through its INDC and other national climate and development plans. Further, through its flagship publication on catalyzing green finance, the ADB found that a critical constraint in promoting climate-friendly investment in the developing member countries was the limited supply of financial and project development support. ${ }^{8}$ As a result, Shandong Province is piloting the Green Finance Catalyst Facility concept (footnote 8) in the SGDF (footnote 5).

In terms of the financial modality for sovereign operations, ADB selected financial intermediation loans (FILs) to support the SGDF. FIL is direct lending to financial intermediaries to finance specific development projects whose individual financing requirements are not large enough to warrant the direct supervision of the ADB. ${ }^{9}$ FIL can be provided on a stand-alone basis, or as components of sector development programs or sector or project loans. In other 
words, the FIL modality allows flexibility in relation to (i) selecting sectors; (ii) building capacity in the channeling institution and stakeholders for further investment; (iii) leveraging PIC finance, if properly structured; and (iv) achieving the required impact and outcome. Given the strategic and pilot nature of the SGDF, a sovereign guarantee was made available for this ADB-financed innovative operation.

\section{PROJECT DEVELOPMENT OBJECTIVES}

The SGDF is an innovative and disruptive financing model for catalyzing green and climate finance and crowding in PIC funds into climate-positive projects. The SGDF aims to support transformative and advanced technology options that can contribute to both SDG's and the PRC's climate commitments. Thus, the SGDF promotes a strategy of low-carbon infrastructure and industrial development while addressing the challenges posed by rapid urbanization, and scaling up action by the public sector to meet the more ambitious goals of ecological civilization of the government. Furthermore, the SGDF is structured to catalyze PIC funding both at the fund and project levels. It will provide a funding contribution of up to $50 \%$ of the project cost to qualifying projects for the first 5-10 years, lowering the risk profile of the climate-friendly projects in order to leverage the remaining financing from PIC sources.

The SGDF will focus on (i) defining aggressive and time-bound umbrella climate change indicators in line with the Green Climate Fund (GCF) investment framework and sector-specific indicators to target better land and water use, and sustainable, low-impact urban development and urban livability; (ii) developing a pipeline of bankable climate friendly projects with at least $25 \%$ "transformational" and 50\% "advanced benefits" (as defined under the GCF investment framework), going beyond renewable power generation and including urban transport, water supply, sanitation, sponge cities and drainage, solid waste recycling and waste-to-energy, and information and communication technology for smart cities to reduce water and carbon footprints and addressing the water-food-energy nexus at the core of its vulnerability; (iii) establishing a financing framework to incentivize such climatefriendly projects to explicitly crowd in PIC finance, and advanced technology to maximize environmental impacts and benefits to the population; and (iv) creating integrated monitoring, evaluation, reporting, and verification systems on both agreed climate and financial indicators based on climate investment eligibility criteria to measure climate impacts, and safeguards monitoring systems.

The SGDF will be structured as an investment pooling vehicle for climate financing. By 2030, the project is expected to reduce $\mathrm{CO}_{2}$ equivalent emissions by 3.75 million tons per year and directly build resilience for 7.5 million people in Shandong Province by 2040, supporting the INDC.
ADB presence is considered critical for the design and establishment of the SGDF, benchmarked to international green and climate best practices in the following aspects:

- Leveraging effect. The SGDF financing will be targeted (climate-related investment), time-bound (5-10 years), and transitional (up to $50 \%$ of project costs for up to 10 years). ADB provides and mobilizes catalytic funding from international financing institutions (IFIs), on which the SGDF depends, to attract local public resources and maximize PIC capital flows into climate-positive projects. The IFIs' contribution to the SGDF (about $\$ 400$ million) is expected to achieve a leveraging ratio over 1:5.10 The level of catalytic funding enables the SGDF to enter subsectors (e.g., low-impact development, sponge cities, urban and rural sanitation, green transport, and the circular economy) which otherwise cannot undertake structural change because of the higher cost of climate-positive investment. The project's design positions the SGDF as an anchor investor to help catalyze significant additional resources. By revolving distributions from shorter-term funds, the SGDF will finance a large number of climate-friendly projects over the 20-year project life span.

\section{- Comprehensive climate investment framework. ADB} designed the assessment and final selection of climatefriendly projects based on climate impacts and benefits (which will be maximized), and bankability (which will be improved). The shift from business as usual, complying with national legislation, to projects delivering advanced and transformational benefits, is supported by the stricter green climate investment criteria enshrined in the loan and project agreements. The SGDF also incentivizes projects to adopt green procurement standards, as greening a project's supply chain so that its shifts from "good practices" to "advanced benefits" will enable access to better financing terms and conditions from the SGDF.

- Project development. The SGDF promotes the adoption of SOURCE, a multilateral digital platform initially developed by ADB and adopted by other IFIs and the private sector, to fast-track the delivery of quality infrastructure projects. ${ }^{11}$ SOURCE is designed to help public sector agencies better prepare, manage, and publish their infrastructure projects to attract private sector investors. This cloud-based system allows the fund management company to present information on all aspects of the development of an infrastructure project for consistency, quality, transparency, and accountability, using sector-specific templates. The project includes a comprehensive digital platform INDEX for an enhanced project management information system for monitoring, evaluation, reporting, and verification, and facilitates reporting to the IFIs and the central and provincial governments. ${ }^{12}$

ADB, \$100 million equivalent in euro; Agence Française de Développement, €70 million; GCF, \$100 million; KfW, €100 million.

SOURCE. http://sif-source.org.

12 INDEX: Financed by the Financial Sector Development Partnership Special Fund (financing partner: Government of Luxembourg) and administered by ADB and developed during the project preparation. 


\section{SHANDONG GREEN DEVELOPMENT FUND: NUTS AND BOLTS}

Structure. The SGDF features a multi-tiered fund structure that addresses an important financial and institutional gap: the timing difference between the development partners' loans (15-20 years) and the investment horizon of PIC investors (5-10 years). The SGDF is structured as limited partnerships and managed by a top-tier fund manager, CICC Capital Management, subsidiary of a leading investment bank, China International Capital Corporation, which is publicly listed on the Hong Kong Stock Exchange.

An innovative financing mechanism, the SGDF includes a 20-year catalytic fund that holds the seed capital from IFIs. On a revolving basis, the catalytic fund will invest in funds blending IFIs and public finance from the Qingdao Municipal Government, Shandong Province with PIC finance at an initial target ratio of 45:55 into a series of shorter-term funds. Each of these shorter-term funds are expected to have an 8- to 10-year lifetime, matching the investment horizon of PIC investors, and provide a non-guaranteed market return to the PIC investors. The SGDF will leverage PIC funding at a market rate in both the SGDF and projects, with reinvesting occurring from years 5 to 15 (Figure 2).
Investment strategy. The SGDF promotes an investment strategy that consists of facilitating the transition to a low-carbon future by encouraging the development of climate-positive projects and leveraging its public funding in Shandong Province. The strategic objective is to tap new funding sources and leverage existing sources of finance into a pipeline of viable climate-friendly investments that (i) ensure the SGDF addresses priority climate impacts and vulnerabilities in Shandong Province, where at least $70 \%$ of the investment will be targeted; (ii) incorporate a project development mechanism funded under the capacity development program to develop a pipeline of climate-positive, sustainable, and replicable projects based on high-level performance against the SGDF Green Climate Assessment Guidelines based on the GCF investment framework; (iii) integrate structures for crowding in PIC finance, targeting pension funds, insurance companies, commercial banks, and corporate investors in the SGDF and in the projects; and (iv) bring into projects the expertise from the private sector and advanced technologies.

Selection criteria. For any project that may be considered for investment under the SGDF, there are two selection criteria that include (i) contribution to climate change mitigation (measured through $\mathrm{CO}_{2}$ equivalent emission reduction) and/or climate change

\section{Figure 2: Shandong Green Development Fund: Innovative Financing Mechanism}

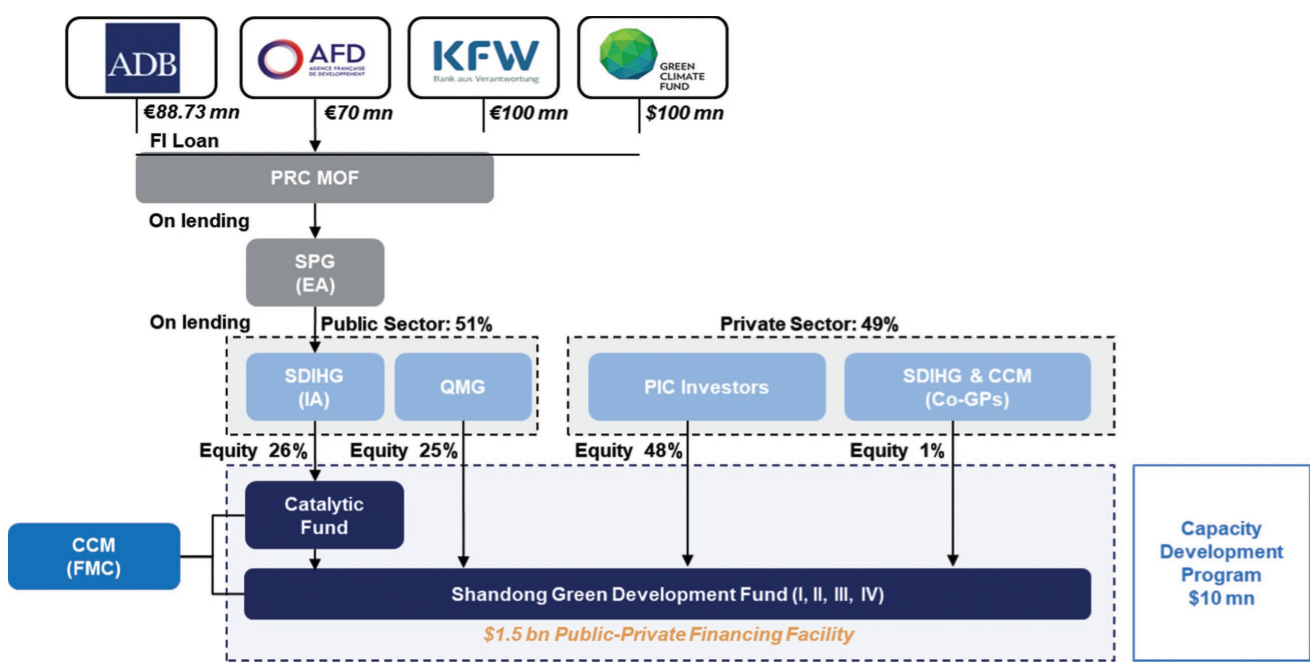

$\mathrm{ADB}=$ Asian Development Bank; AFD = Agence Française de Développement; CCM = CICC Capital Management; EA = executing agency; $\mathrm{FI}$ = financial intermediation; $\mathrm{FMC}=$ fund management company; $\mathrm{GP}=$ general partner; $\mathrm{IA}=$ implementing agency; $\mathrm{mn}=$ million; $\mathrm{MOF}=\mathrm{Ministry}$ of Finance; PIC = private, institutional, and commercial; PRC = People's Republic of China; QMG = Qingdao Municipal Government; SDIHG = Shandong Development \& Investment Holding Group; SPG = Shandong Provincial Government.

Source: ADB. 2019. Report and Recommendation of the President to the Board of Directors: Proposed Loan to the People's Republic of China for Shandong Green Development Fund Project. Manila. 


\section{Table 1: Shandong Green Development Fund: Examples of Climate-Friendly Projects}

\begin{tabular}{|c|c|c|}
\hline Project Name & Scope & Climate Focus \\
\hline $\begin{array}{l}\text { Energy Management for } \\
\text { Zero Energy-Zero Waste } \\
\text { at Expressway Service } \\
\text { Centers }\end{array}$ & $\begin{array}{l}\text { The project promotes low-carbon circular } \\
\text { development by introducing renewable } \\
\text { energy, improved energy efficiency, and the } \\
\text { promotion of electric vehicles charging to } \\
\text { reduce GHG emission at } 35 \text { twin expressway } \\
\text { service areas in Shandong. }\end{array}$ & $\begin{array}{l}\text { The project replaces } 14 \text { million } \mathrm{kWh} \text { of grid-supplied power } \\
\text { annually and reduces } \mathrm{CO}_{2} \text { emission by about } 5.82 \text { million tons } \\
\text { over the project's lifetime. A regenerative circular economy } \\
\text { approach is applied to management, re-use and treatment of } \\
\text { rainfall runoff, digestion of wastes, waste recycling, and climate- } \\
\text { resilient design of accommodation and shopping areas. The } \\
\text { project also contributes to Shandong Low Carbon Development } \\
\text { Action Plan (2017-2020). }\end{array}$ \\
\hline $\begin{array}{l}\text { Solar Smart-Grid } \\
\text { for Inclusive Access } \\
\text { to Information } \\
\text { Communication } \\
\text { Technology }\end{array}$ & $\begin{array}{l}\text { Solar panels are installed on thousands of } \\
\text { telecommunication towers in Shandong. Each } \\
\text { solar smartgrid is integrated into the national } \\
\text { power grid and supplies } 20-25 \mathrm{kWh} \text { per day } \\
\text { to each tower to improve } 4 \mathrm{G} \text { expansion, WiFi, } \\
\text { and Internet of Things. }\end{array}$ & $\begin{array}{l}\text { By replacing } 175 \text { million } \mathrm{kWh} \text { of grid-supplied power annually, } \\
\text { the project contributes to the decarbonization of Shandong } \\
\text { Province. The project enables } 52,500 \text { tons of coal substitution } \\
\text { annually and reduces } \mathrm{CO}_{2} \text { emissions by } 3.94 \text { million tons. }\end{array}$ \\
\hline $\begin{array}{l}\text { Large-Scale Biomass } \\
\text { Delivers Decarbonization }\end{array}$ & $\begin{array}{l}\text { The project constructs and operates } \\
\text { agricultural and animal husbandry waste } \\
\text { recycling facilities at three locations in } \\
\text { Shandong. The project treats agricultural waste } \\
\text { in an environment-friendly manner, reduces } \\
\text { point source pollution, and provides high-value } \\
\text { fertilizer while reducing GHG emission. }\end{array}$ & $\begin{array}{l}\text { The biomass-to-energy generates up to } 140 \text { million } \mathrm{kWh} \\
\text { of electricity per year from each of the three installations, } \\
\text { reducing reliance on coal and providing a clean product. } \\
\text { Direct beneficiaries at the three locations total } 11,475 \text { people } \\
\text { temporary and long-term employed. The project saves } \\
126,400 \text { tons of coal annually, or } 79.8 \text { million tons of } \mathrm{CO}_{2} \\
\text { emission over its lifetime. }\end{array}$ \\
\hline
\end{tabular}

$4 \mathrm{G}$ = fourth generation (mobile technology), $\mathrm{CO}_{2}=$ carbon dioxide, $\mathrm{GHG}=$ greenhouse gas, $\mathrm{kWh}=$ kilowatt-hour .

Source: ADB. 2019. Report and Recommendation of the President to the Board of Directors: Proposed Loan to the People's Republic of China for Shandong Green Development Fund Project. Manila.

adaptation (measured through improvement of the beneficiaries' resilience), and (ii) meeting the eligibility criteria agreed with the development partners following the GCF investment framework.

Further, all investments will be screened with the criteria set under the SGDF Green Climate Assessment Guidelines (footnote 5) based on the GCF investment framework. Climate-friendly projects will be enhanced through the capacity development program to maximize their climate benefits and the adoption of high-level technologies. All investments will be evaluated based on financial, economic, commercial, legal, and safeguards due diligence.

Initial project portfolio. The project preparation validated the SGDF Green Climate Assessment Guidelines, the cost estimates, and the climate mitigation and adaptation benefits on 10 project concepts, including three pre-feasibility studies as shown in Table 1.

The total cost of those three indicative projects is more than $\$ 600$ million, with a total $\mathrm{CO}_{2}$ equivalent emissions reduction of 3.5 million tons per year corresponding to a displacement of about 178,000 tons of coal, and resulting in an annual reduction of 2,000 tons of nitrogen oxide and 3,700 tons of sulfur dioxide. One project linked to fossil fuels (improving boiler efficiency) was dropped and six projects are under further preparation. Some of the transformational businesses are still in the research and development stage and require strong public funding and further policy support before being considered for financing by the SGDF. However, these businesses could receive SGDF financing over the fund's 20-year life.

The transformational businesses headquartered in Shandong Province are a testimony to the commitment of the Shandong Provincial Government to develop policies targeting climate resilience, coal substitution, and transition to a low-carbon economy, as presented in Table 2.

\section{CONCLUSION}

The SGDF will contribute to the achievement of the SDGs and address key policy constraints limiting climate-friendly investment, and support ADB Strategy 2030 and the government's INDC. The SGDF is designed to leverage public funding and crowd in PIC capital targeting climate-friendly investments through differential pricing. The level of catalytic funding in a climate-friendly project is determined through the rigorous application of the GCF investment framework customized under the SGDF Green Climate Assessment Guidelines, supplemented by an international green rating of each project and monitored with a digital platform INDEX. The capacity development program funded under the ADB loan includes a project development facility to support transformational climate-positive projects and to maximize climate benefits. 
Table 2: Shandong Provincial Government: Examples of Transformational Climate-Friendly Projects

\begin{tabular}{|c|c|c|}
\hline Project Name & Scope & Climate Focus \\
\hline $\begin{array}{l}\text { Pre-Cast Solutions Building } \\
\text { Climate Resilience }\end{array}$ & $\begin{array}{l}\text { Businesses manufacture safe, clean, and } \\
\text { energy efficient pre-cast concrete frames } \\
\text { using green procurement on the supply } \\
\text { chain and reducing the construction time } \\
\text { on-site. }\end{array}$ & $\begin{array}{l}\text { The off-site manufacturing results in significant energy savings } \\
\text { (green buildings) through standardization and optimization of } \\
\text { design and manufacturing processes as well as safe, energy- } \\
\text { efficient buildings with major environmental and economic } \\
\text { co-benefits for the vulnerable part of the population (social } \\
\text { housing, schools, hospitals). }\end{array}$ \\
\hline $\begin{array}{l}\text { Disruptive "Hydrogen } \\
\text { Valley" Leads the Charge } \\
\text { for Urban Mobility }\end{array}$ & $\begin{array}{l}\text { The SPG is financing a technology park } \\
\text { called "Hydrogen Valley" to regroup all the } \\
\text { R\&D and manufacturing businesses related } \\
\text { to the production, distribution, and storage } \\
\text { of hydrogen for mobility. }\end{array}$ & $\begin{array}{l}\text { The hydrogen substitutes fossil fuels, especially for } \\
\text { transportation. This transformational technology just starting } \\
\text { with commercial application is safer and more convenient for } \\
\text { vehicles charging compared to e-vehicles. }\end{array}$ \\
\hline $\begin{array}{l}\text { Travel to the Future on } \\
\text { Smart Solar Highway }\end{array}$ & $\begin{array}{l}\text { A prototype solar road of } 2 \text { kilometers is } \\
\text { piloted in Shandong Province with various } \\
\text { tests in } 2018 \text { and } 2019 .\end{array}$ & $\begin{array}{l}\text { The transformational technology (still in R\&D) of solar } \\
\text { roads supports (i) wireless charging of vehicles while driving, } \\
\text { (ii) self-driving vehicles, (iii) loT backbone infrastructure along } \\
\text { roads including Wi-Fi applications, (iv) micro-grid applications, } \\
\text { and (v) energy production to the grid. }\end{array}$ \\
\hline
\end{tabular}

loT = Internet of Things, R\&D = research and development, SPG = Shandong Provincial Government.

Source: ADB. 2019. Report and Recommendation of the President to the Board of Directors: Proposed Loan to the People's Republic of China for Shandong Green Development Fund Project. Manila.

About the Asian Development Bank

$A D B$ is committed to achieving a prosperous, inclusive, resilient, and sustainable Asia and the Pacific, while sustaining its efforts to eradicate extreme poverty. Established in 1966, it is owned by 68 members49 from the region. Its main instruments for helping its developing member countries are policy dialogue, loans, equity investments, guarantees, grants, and technical assistance.

ADB Briefs are based on papers or notes prepared by ADB staff and their resource persons. The series is designed to provide concise, nontechnical accounts of policy issues of topical interest, with a view to facilitating informed debate. The Department of Communications administers the series.

Notes:

In this publication, "\$” refers to United States dollars. ADB recognizes "China" as the People's Republic of China and "Hong Kong" as Hong Kong, China.
The views expressed in this publication are those of the authors and do not necessarily reflect the views and policies of ADB or its Board of Governors or the governments they represent. ADB encourages printing or copying information exclusively for personal and noncommercial use with proper acknowledgment of ADB. Users are restricted from reselling, redistributing, or creating derivative works for commercial purposes without the express, written consent of ADB.

Asian Development Bank

6 ADB Avenue, Mandaluyong City

1550 Metro Manila, Philippines

Tel +63286364444

Fax +63286362444

www.adb.org/publications/series/adb-briefs 